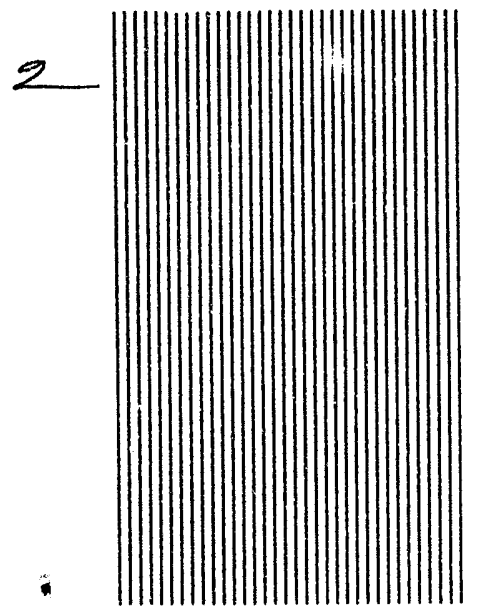

\title{
FUEL QUALITY ISSUES \\ IN THE OIL HEAT INDUSTRY
}

TOPICAL REPORT

Wai-Lin Litzke

December 1992

Prepared for:

Building Equipment Division

BNL-48524

Informal Report

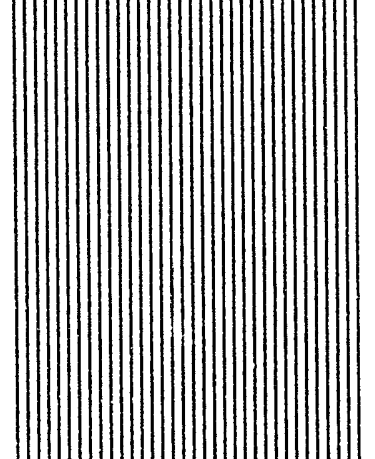

Office of Building Technologies

F.

$$
\begin{aligned}
& \text { A. } 191 \mathrm{P} \\
& 6, \mathrm{~B} !
\end{aligned}
$$

United States Department of Energy

\section{Energy Efficiency and Conservation Division DEPARTMENT OF APPLIED SCIENCE}

BROOKHAVEN NATIONAL LABORATORY UPTON, LONG ISLAND, NEW YORK 11973

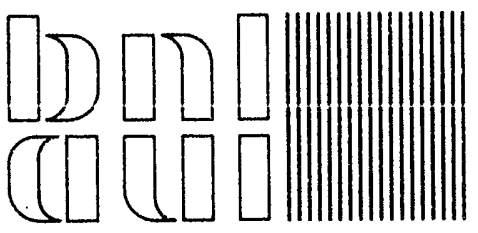




\title{
FUEL QUALITY ISSUES \\ IN THE OIL HEAT INDUSTRY
}

TOPICAL REPORT

\author{
Wai-Lin Litzke
}

December 1992

Energy Efficiency \& Conservation Division

Tepartment of Applied Science

Brookhaven National Laboratory

Upton, New York 11973

This work was performed under the auspices of the U. S. Department of Energy

Washington, D.C. under Contract No. DE-AC02-76CH00016 


\section{DISCLAIMER}

This report was prepared as an account of work sponsored by an agency of the United States Government. Neither the United States Government nor any agency thereof, nor any of their employees, nor any of their contractors, subcontractors, or their employees makes any warranty, express or implied, or assumes any legal liability or responsibility for the accuracy, completeness, or usefulness of any information, apparatus, product or process disclosed, or represents that its use would not infringe privately owned rights. Reference herein to any specific commercial product, process, or service by trade name, trademark, manufacturer, or otherwise, does not necessarily constitute or imply its endorsement, recommendation, or favoring by the United States Government or any agency thereof. The views and opinions of authors expressed herein do not necessarily state or reflect those of the United States Government or any agency, contractor, or subcontractor thereof. 


\section{TABLE OF CONTENTS}

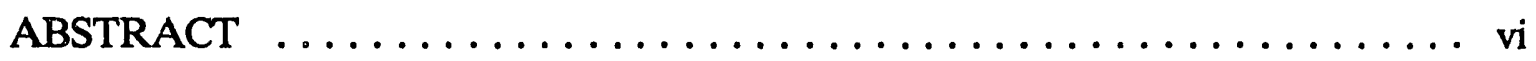

1. INTRODUCTION $\ldots \ldots \ldots \ldots \ldots \ldots \ldots \ldots \ldots \ldots \ldots \ldots \ldots \ldots \ldots \ldots \ldots$

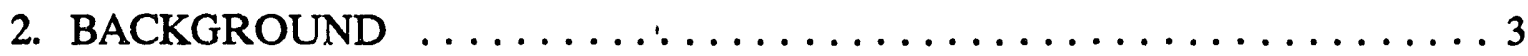

3. REFINING TRENDS $\ldots \ldots \ldots \ldots \ldots \ldots \ldots \ldots \ldots \ldots \ldots \ldots$

3.1 Impacts of the Clean Air Act $\ldots \ldots \ldots \ldots \ldots \ldots \ldots \ldots \ldots \ldots$

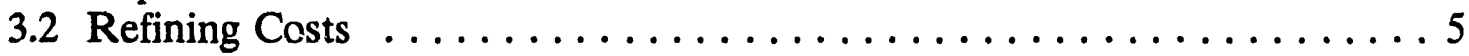

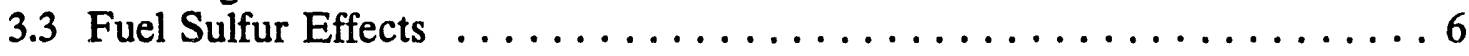

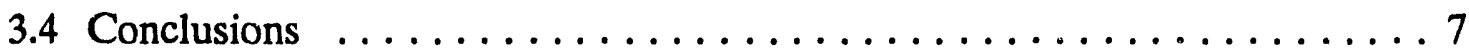

4. FUEL PROPERTY EFFECTS $\ldots \ldots \ldots \ldots \ldots \ldots \ldots \ldots \ldots$

4.1 Low Temperature Fuel Characteristics $\ldots \ldots \ldots \ldots \ldots \ldots \ldots$ Cloud and Pour Point Temperature Effects Cold Flow Improvers Viscosity Effects

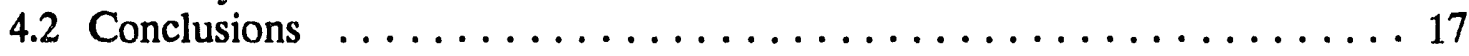

5. CONTAMINATION $\ldots \ldots \ldots \ldots \ldots \ldots \ldots \ldots \ldots \ldots \ldots \ldots \ldots$

5.1 Water and Microbiological Contamination .............. 19

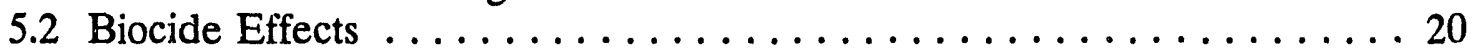

6. CLOSING DISCUSSIONS $\ldots \ldots \ldots \ldots \ldots \ldots \ldots \ldots \ldots \ldots \ldots \ldots \ldots \ldots$

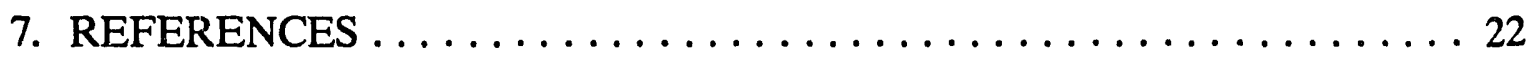

8. APPENDIX - Biocides Experiment $\ldots \ldots \ldots \ldots \ldots \ldots \ldots \ldots \ldots \ldots 24$ 


\section{LIST OF TABLES}

Page

1. Environmental Costs Associated with Oil Burners ............. 7

2. ASTM Specification for Some Properties $\ldots \ldots \ldots \ldots \ldots \ldots$ 


\section{LIST OF FIGURES}

1. .enth Percentile Minimum Temperatures for January and February . . . . 12

2. Effect of Kerosene Blending on Cloud Point for Four Fuel Samples . . . . . 13

3. Effect of Kerosene Blending on Pour Point for Four Fuel Samples . . . . . 13

4. Effect of Additive $1 \mathrm{~A}$ on Pour Point of Four Heating Oil Samples . . . . 14

5. Effect of Additive 1B on Pour Point of Four Heating Oil Samples . . . . . 14

6. Viscosity-Temperature Profile for Typical No. 2 Fuel Oil . . . . . . . . . 15

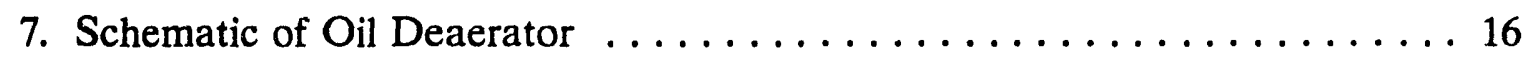

8. Temperature-Time Profile of Oil in Deaerator $\ldots \ldots \ldots \ldots \ldots \ldots$

9. Water Bottom Microorganism Populations in Heating Oil Distribution System . . . . . . . . . . . . . . . . . . . . . . 19

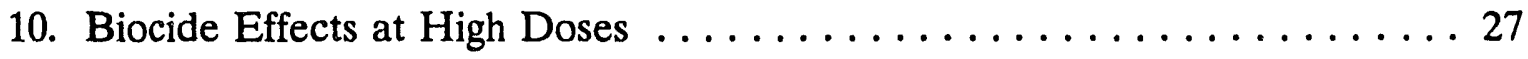

11. Biocide Effects at Manufacturer's Recommended Doses . . . . . . . . . . 28

12. Biocide Effects at Low Doses . . . . . . . . . . . . . . . . . . 29 


\begin{abstract}
The quality of fuel oil plays an essential role in combustion performance and efficient operation of residential heating equipment. With the present concerns by the oil-heat industry of declining fuel-oil quality, a study was initiated to identify the factors that have brought about changes in the quality of distillate fuel. A background of information will be provided to the industry, which is necessary to deal with the problems relating to the fuel.
\end{abstract}

The high needs for servicing heating equipment are usually the result of the poor handling characteristics of the fuel during cold weather, the buildup of dirt and water in storage tanks, and microbial growth. A discussion of how to deal with these problems is presented in this paper. The effectiveness of fuel additives to control these problems of quality is also covered to help users better understand the functions and limitations of chemical treatment. Test data have been collected which measure and compare changes in the properties of fuel using selected additives. A booklet following from this work and published separately gives recommendations and guidelines for educating fuel suppliers and end users on how to minimize some common problems. This reference document is entitled "Maintenance and Storage of Fuel Oil for Residential Heating Systems - A Guide for Residential Heating System Personnel." 


\section{INTRODUCTION}

Many factors have been cited as the causes of declining fuel quality by representatives of the heating industry and in the literature. The first group of factors is related to the quality of the crude oil sources from which the fuel originated, and the severity of refining methods that go into processing the final products, which strorigly influence the properties and characteristics of the end products. Changes towards heivier feedstocks and new refining strategies to meet the demand for distillate fuel can produce products with heavier compounds (lower API gravity), higher viscosity, and higher sulfur content [2].

The second group of factors that strongly determines the overall quality of the fuel after it leaves the refinery is associated with the conditions of the storage facility. A storage facility such as a tank, or tanker truck that is not well maintained and allows contaminants to enter the fuel contributes to many of the perceived fuel problems that the typical fuel marketer or homeowner encounters. The contaminants are a combination of fuel degradation products, water, microbiological growth, and other foreign matter (such as rust, dirt, and corrosion debris). These contaminants lead to the formation of sludge and, therefore, increase the chances of plugging fuel lines and filters In turn, this raises service needs and reduces efficient operations of heating equipments.

The strong interest in issues of fuel quality formed the basis for the studies conducted at Brookhaven National Laboratory (BNL) within the Combustion Equipment Technology program in the area of Fuels, Fuel Quality, and Storage. The following objectives of the study were accomplished in three phases:

(Phase 1)

- to develop an overall view of the factors that have brought about changes in the quality of distillate fuel,

- to identify the range of problems and concerns with No. 2 fuel oil amongst the oil heat industry,

- to examine trends in the properties of fuel oil

(Phase 2)

- to quantify the effectiveness of commonly used chemical additives in modifying measurable fuel properties,

- to develop guidelines on monitoring heating fuel, using chemical additives, and minimizing the associated storage problems 


\section{(Phase 3)}

- to study and measure the effects of varying fuel properties on combustion performance,

- to evaluate current fuel specifications and identify ranges to achieve reliable equipment operations, and reduced emissions

The results of Phase 1 are published in an informal BNL report [1]. A summary of

Phase 1 conclusions and detailed results from Phase 2 are presented in this paper. Data from the Phase 3 study will be assembled in a separate topical report. 


\section{BACKGROUND}

Low fuel quality is often reflected in poor handling properties (high viscosity, high cloud and pour points), poor combustion performance (lower BTU content and lower cetane), or poor stability in storage (increased tendency to form gums and sediments). In a BNL survey [1] of oil marketers selling No.2 fuel, service managers, and manufacturers of heating equipment, the most common problems observed in the field are caused by the buildup of sludge and sediment in homeowners' tanks. Plugged nozzles, clogged filters, and pump screens contribute to the highest service needs. Many of these problems relate to the fuel itself or the contamination of the fuel during storage.

As part of Phase 1 of this project, a broad-based sampling program was conducted to establish a database of information on fuel properties. Fresh fuels were obtained from fuel marketers as well as from residential tanks. The analytical results obtained were used to determine the range of variations in the property of fuels currently being supplied to the domestic heating market. Samples obtained from selected residential tanks provided information on the type of fuel-re!ated problems that are found in the field and some information on specific storage conditions.

Analyses of the chemical and physical properties of the fuels showed variability in viscosity, sulfur and cloud and pour points, specific gravity, and heat content, most of which were within ASTM limits. There were occasional samples (less than 5\%) with properties exceeding ASTM limits for viscosity, sulphur, or specific gravity. Data reported for fuel oil at refinery outputs on a national basis (NIPER - 1989) [8] showed some regional variability in sulfur content $(0.151$ to $0.326 \mathrm{wt} \%)$ and viscosity ( 2.52 to 2.96 cSt at $104^{\circ} \mathrm{F}$ ), but little variability in other properties.

In general, the quality of distillate fuel is consistent with current specifications (ASTM). However, without any controls or regulations there are reasons to believe that the quality of heating fuel will decline. Heavier crude oils with higher sulfur contents have resulted in the declining quality of crude oil [2]. This trend can result in higher sulfur content in the distillate fractions. The trend towards increased conversion of heavy components into light products could result in higher levels of aromatics in the future [3]. Increased use of high aromatic fractions, such as light cycle oils, in blending distillate fuels have been associated with higher sediment formation and reduced inherent stability of the final product [4].

The use of chemical additives to restore or prevent fuel from degrading is becoming more and more common. Over half of the respondents (68\%) from the survey said that they use chemical additives to improve fuel oil quality. Numerous types of commercial additives are available but its often difficult to select among them. The confusion begins with all the advertising claims and testimonials accompanying the products. This strong interest in additives formed the basis for the current Phase 2 study, which was to evaluate the capabilities and limitations of chemical treatment. 


\section{REFINING TRENDS}

\subsection{Impacts of Clean Air Act}

One of the goals of the Clean Air Act Amendments (CAA) of 1990 is to reduce toxic and particulate emissions from trucks and buses, which are vategorized as onhighway vehicles. The method by which this was to be achieved is by reducing the maximum permissible sulfur content of on-highway diesel fuel to 0.05 percent by weight and limiting the aromatic content (minimum cetane index of 40) beginning in October 1993. This new standard will apply to the entire nation and will affect approximately 42 percent of the combined consumption of diesel fuel and home heating oil.

With the established limits on sulfur and aromatic content in diesel fuel, the oil-heat industry has been concerned about what this will do to the heating fuel because both diesel and No. 2 heating oil have always been derived from the same pool. If these products were segregated into two pools, then refineries could change blending practices to direct low sulfur blend stocks to the diesel pool and use the heating oil pool as a sink for more undesirable products. Although predictions of fo'ture refining practices and marketing strategies cannot be made, there are implications of how these issues might affect the residential heating industry. The following paragraphs will review several published studies which discuss current considerations, specific plans, and some concerns of industry and government.

Since 1985, many studies have been conducted by the U.S. Environmental Protection Agency (EPA), the refining industry, and the automotive industry to investigate the costs and impacts of restrictions on the sulfur and aromatic content of highway diesel fuel $[3,5,6,7]$. One of the biggest factors that will affect final costs is the amount of the fuel to be desulfurized, which depends on the degree of segregation which will be accomplished between regulated (diesel) and non-regulated fuels (heating and other off-highway fuels). Complete segregation would mean less fuel would have to be treated (only the highway fuel) and represents the lower-bound costs. In reality, the extent of segregation may be much less because many refineries produce these fuels for dual purposes. If current practices were maintained, some off-highway fuels also would be treated, thereby increasing the costs of refining, representing upper-bound costs.

Some cost evaluations were done on the capabilities of segregating distribution systems within the refineries. One study suggested that although the requirements for segregating facilities vary and these estimates vary widely from plant to plant, the magnitude of savings from segregation showed that refining as a whole would not justify new segregation facilities [7].

A recent survey of refiners in 1991 included those companies with a collective operating facility of $50 \%$ of the total U.S. distillation capacity. This survey provided the latest insight into the refining industries' plans for complying with all CAA regulations on 
mobile sources [8]. With regard to the requirements for reduced sulfur, this survey revealed that:

- About $75 \%$ of the group plan to produce the majority of their diesel and heatingoil stream as low sulfur $(0.05 \%)$ product, and do not anticipate any particular problems in doing so.

- About one-half of the companies plan to continue producing a high-sulfur diesel fuel, as well as introduce a new low-sulfur grade to meet the Oct. 1, 1993 deadline.

- With the exception of coastal refiners with ready access to the Northeast heating fuel market, most respondents plan to produce only a single grade of diesel with $0.05 \%$ sulfur.

Although the EPA and the refining industry have provided a broad picture of the probable trends in the near future, there is still a great deal of uncertainty. Diesel hydrotreating facilities or other alternatives which are required for desulfurization will need to be built or significantly expanded. Many refiners surveyed had not fully developed their plans for meeting the 1993 standard nor determined their future facility requirements [8]. At the level downstream of the refinery, other factors, such as the cost effectiveness of segregation, i.e. tankage and storage capabilities, have not been clearly determined.

\subsection{Refining Costs}

As discussed earlier, many variables affect the costs in controlling the quality of diesel fuel. Estimates generated by the EPA and the refining industry vary broadly. EPA has published "best estimate" refinery costs for reduced sulfur that range from 1.8 to 2.3 cents per gallon of controlled fuel (or $\$ 360$ - $\$ 830$ million/ year based on anticipa ed volume of controlled fuel); subsequent control of aromatics costs from $2.1-2.4$ cents per gallon of controlled fuel ( $\$ 470-\$ 770$ million year) [3].

Based on the information from the refinery survey and other independent studies, cost premiums associated with the production of a low-sulfur grade will be 4 to 7 cents per gallon, including capital recovery and operating costs. Smaller refiners, particularly those under 20,000 barrels per day, will find it much more difficult to add hydrotreating facilities and will be significantly disadvantaged by the new specifications [8].

The investment in new refining and storage facilities, and additional associated operating costs will undoubtedly be reflected in final product prices. Much analysis has been done to evaluate the significant benefits which can be derived in using low-sulfur oil to reduce vehicle emissions exhaust and engine wear. Similar benefits can also be 
realized when using low sulfur fuels in residential heating equipment. The advantages are discussed in the next section on the effects of fuel sulfur.

\subsection{Effects of Fuel Sulfur}

Some refiners probably will treat the whole distillate pool, and thus, at least some of the fuel oil marketed, will have a low sulfur content, or a low sulfur and aromatics content. This will reduce emissions for sources that use this fuel oil.

The content of sulfur in the fuel will primarily affect the total sulfur-oxide emissions. Over $95 \%$ of the sulfur is emitted as sulfur dioxide $\left(\mathrm{SO}_{2}\right)$, while the rest is emitted as sulfate particulates and sulfur trioxide, which quickly reacts with moisture to become additional sulfate particulates or sulfuric acid. Reducing sulfur from a typical value of $0.25 \mathrm{wt} \%$ (national average) to $0.05 \mathrm{wt} \%$ will reduce sulfur oxide emissions by $80 \%$.

Sulfur dioxide is a toxic air pollutant which contributes to the formation of acid rain resulting in physical damages, such as loss of crops. To measure the environmental and physical damages resulting from acid rain, oil- and coal-fired power utilities, and regulatory agencies use as a guide an analysis which assigns a numerical cost factor for various pollutants [15]. Although the proposed estimates for these cost factors are preliminary and vary over a wide range, they provide a potential method for quantitatively comparing the "negative" impacts of a pollutant with the cost associated with controlling it. This type of analysis has been used to evaluate and compare control options for air pollution.

An attempt to evaluate the environmental impacts of oil use with residentiai heating equipment in terms of cost was recently done using the above analysis. Using the same reasoning, the benefits associated with using low sulfur fuels in heating equipment can be determined. As a basis, fuels containing typical sulfur levels of $0.25 \%$ was assumed. The environmental or "negative" costs for each fuel type are calculated and the difference in these values compared to the costs in producing low-sulfur fuel. Table 1 shows this comparison, using EPA emissions data for residential heating equipment. The results suggest that the environmental cost is comparable to the refining costs associated with fuel desulfurization. 
Rate of Sulfur Oxides Emissions

Cost of Sulfur Oxides Pollutant ${ }^{1}$

Environmental Cost/ gallon of $0.25 \%$ fuel

Environmental Cost/ gallon of $0.05 \%$ fuel

Environmental Cost Difference

Fuel Desulfurization and

Aromatics Control
$36 \mathrm{lb} / 1000 \mathrm{gal}$

$88 \lessdot / \mathrm{lb}$

$3.2 \notin / \mathrm{gal}$

$0.6 \notin / \mathrm{gal}$

$2.6 \notin / \mathrm{gal}$

$1.8-4.7 \propto / \mathrm{gal}$

1 Reference [16]

Table 1 - Environmental Costs Associated with Oil Burners

Basis: Fuel oil containing $0.25 \%$ by wt.

EPA emissions data for residential furnace

Sulfuric acid is another by-product of sulfur oxidation and is a serious concern to boiler operators since it corrodes combustion equipment. About $1 \%$ of the fuel sulfur is converted to sulfuric acid during combustion and can condense onto heat-exchanger surfaces, corroding them and producing iron-sulfate scale. BNL has an ongoing project to measure the effects of sulfur content on heat-exchanger fouling. The results show that iron-sulfate scale increases proportionally with the sulfur level in the fuel [9].

\subsection{Conclusions}

Tougher federal regulations to reduce the sulfur content in diesel fuels and comply with CAA requirements will impact heavily on the capabilities of the refining industry. In recent years, refiners have increased the capacity of hydrotreaters and desulfurization units to deal with the decline in the quality of crude oil and to meet the requirements for low-sulfur fuels. Increased processing, more severe methods, and higher investment costs are anticipated, although these factors will vary widely, based on refinery size, crude feedstock, and the current configuration of the refinery. Balancing the federal law requirements and satisfying the increased demands for high-quality products will challenge the petroleum industry over the next decade.

The future quality of non-regulated distillate fuels, such as home-heating fuel depends largely on the fuel-oil marketers' expectations. Purchase specifications and quality control on distillate products will enable quality to be maintained. It is likely that in many refineries more than just on-highway diesel fuel will be treated, and therefore, lowand high-sulfur fuels will become available for the heating market. In future, refiners may be motivated to refine all heating oil and diesel fuels to the same low-sulfur 
specification to reduce the costs associated with segregation, distribution limitations, and to satisfy the marketers who specify a higher quality product.

Benefits will accrue from using low-sulfur fuels. Emissions of sulfur oxides and the associated environmental costs can be reduced. Minimizing the fouling of heat exchangers can extend equipment wear, reduce maintenance requirements, and achieve better thermal efficiency. 


\section{FUEL PROPERTY EFFECTS}

\subsection{Characteristics of Low-Temperature Fuel}

The following section will examine the effects on the performance of heating equipment of standard fuel properties, cloud and pour point, and viscosity. These characteristics undergo physical changes at low storage or operating temperatures and are the major causes of poor handling conditions in cold weather, such as the plugging of fuel lines and filters, and poor atomization. Solvents, or dissolving agents, such as kerosene, have traditionally been used as well as other chemical additives to minimize these problems. Their effectiveness and the limitations will be discussed.

Table 2 lists the typical specifications (ASTM) for these properties.

\begin{tabular}{||l|l|l|}
\hline Property & $\begin{array}{l}\text { Heating Fuel Limits } \\
\text { ASTM D-396 }\end{array}$ & $\begin{array}{l}\text { Diesel Fuel Limits } \\
\text { ASTM D-975 }\end{array}$ \\
\hline \hline Cloud point & No requirements & Local 1 \\
Pour point & $-6^{\circ} \mathrm{C}\left(20^{\circ} \mathrm{F}\right) \max$ & No requirements \\
$\begin{array}{l}\text { Viscosity at } \\
40^{\circ} \mathrm{C}\left(104^{\circ} \mathrm{F}\right)\end{array}$ & $1.9-3.4 \mathrm{cSt}$ & $1.9-4.1 \mathrm{cSt}$ \\
\hline
\end{tabular}

1 This temperature is not broadly specified. Satisfactory operation should be achieved in most cases if the cloud point (or wax appearance point) is specified at $6^{\circ} \mathrm{C}$ above the tenth percentile minimum ambient temperature for the area in which the fuel will be used.

Table 2 - ASTM specifications for some properties of fuel

In the standard ASTM D-975, the 10th percentile minimum ambient temperature is defined as the lowest temperature which will occur $90 \%$ of the time; in other words, there is only a $10 \%$ expectation that the minimum daily temperature will be lower than this. This temperature is calculated for each month from October to March for different regions of the United States, and assists with determining appropriate cloud point temperatures. As an example, Figure 1 shows the values for January and February, typically the two coldest months of the year for the Northeast region.

Distillate fuels, such as heating oil and diesel, contain hydrocarbon waxes which become insoluble and crystallize at low temperatures. Crystals first appear when the fuel is cooled down to the cloud-point temperature. As the temperature drops further, more wax crystals form and tend to gel together until the fuel barely flows. At this point, the 
pour-point temperature has been reached. These conditions can reduce the ability for the fuel to flow through fuel lines and filters, which can present a big problem for heating systems with supply and return lines where large volumes of fuel are circulated.

Adhering to the specifications for cloud and pour points is critical during cold weather operations, especially if the heating equipment and storage systems encounter ambient outdoor temperatures. In most cases, fuels sold during the winter should comply with the local requirements; fuels sold during the summer months, however, can have higher cloud- and pour-points. These temperatures are easily measured using ASTM Methods D2500 and D97, respectively, and should be routinely monitored to ensure satisfactory operation.

Blending of No. 2 oil with solvents and chemical additives can improve the flow of the fuel at low temperatures. Kerosene is commonly used to improve fluidity of the fuel at low temperatures. It acts as a solvent to dissolve the waxes and effectively reduces the cloud- and pour-point temperatures, so that the blended mixture will continue to flow at lower temperatures. Measurements were taken in the laboratory to determine these effects. Figures 2 and 3 illustrate the response of four different heating oils with kerosene concentrations of up to $70 \%$ by volume. The results show that kerosene blending is an effective way of lowering both the cloud- and pour-points. Fuels with initially higher pour-points (at $0 \%$ blend) show the greatest reduction in pour-point temperatures after blending.

Based on our measurements, flow improver additives or pour-point depressants also can be used to effectively depress pour-point. The additives are polymeric materials that interact with wax crystals in the fuel and modify their growth, making them smaller and less prone to form large particles. These flow improvers work in two ways, by nucleation and by growth inhibition. By inhibiting growth of large networks of wax crystals, fuel does not gel as readily and its pour-point is lowered.

The improvement provided by an additive will depend on the characteristics of the fuel as well as on the additive itself. One of the most important fuel characteristics influencing additive response is its wax content, which will depend on the crude type, distillation range and the sources of the blend components used in the fuel. Using flow improvers is an effective way of preventing problems associated with wax formation. Once wax is formed, the use of an additive will not change the waxes already present, although, if the temperature falls lower, it will interact with and modify newly separating waxes.

Figures 4 and 5 show the effects of two different types of additives, at different concentrations, on four typical heating oils. The treatments are expressed in ppm (1000 ppm equals 1 gallon of additive/1000 gallons of fuel). We conclude from these tests that: 
- The improvement (or temperature depression) provided by an additive will depend on the characteristics of the fuel,

- Different fuels will exhibit different behaviors, even though they are all classified as heating oil,

- Some additives are more effective than others at the same concentration,

- Much less chemical additive is needed to effectively reduce pour-point compared to the volume of kerosene required,

- Chemical additives have little effect on cloud-point 


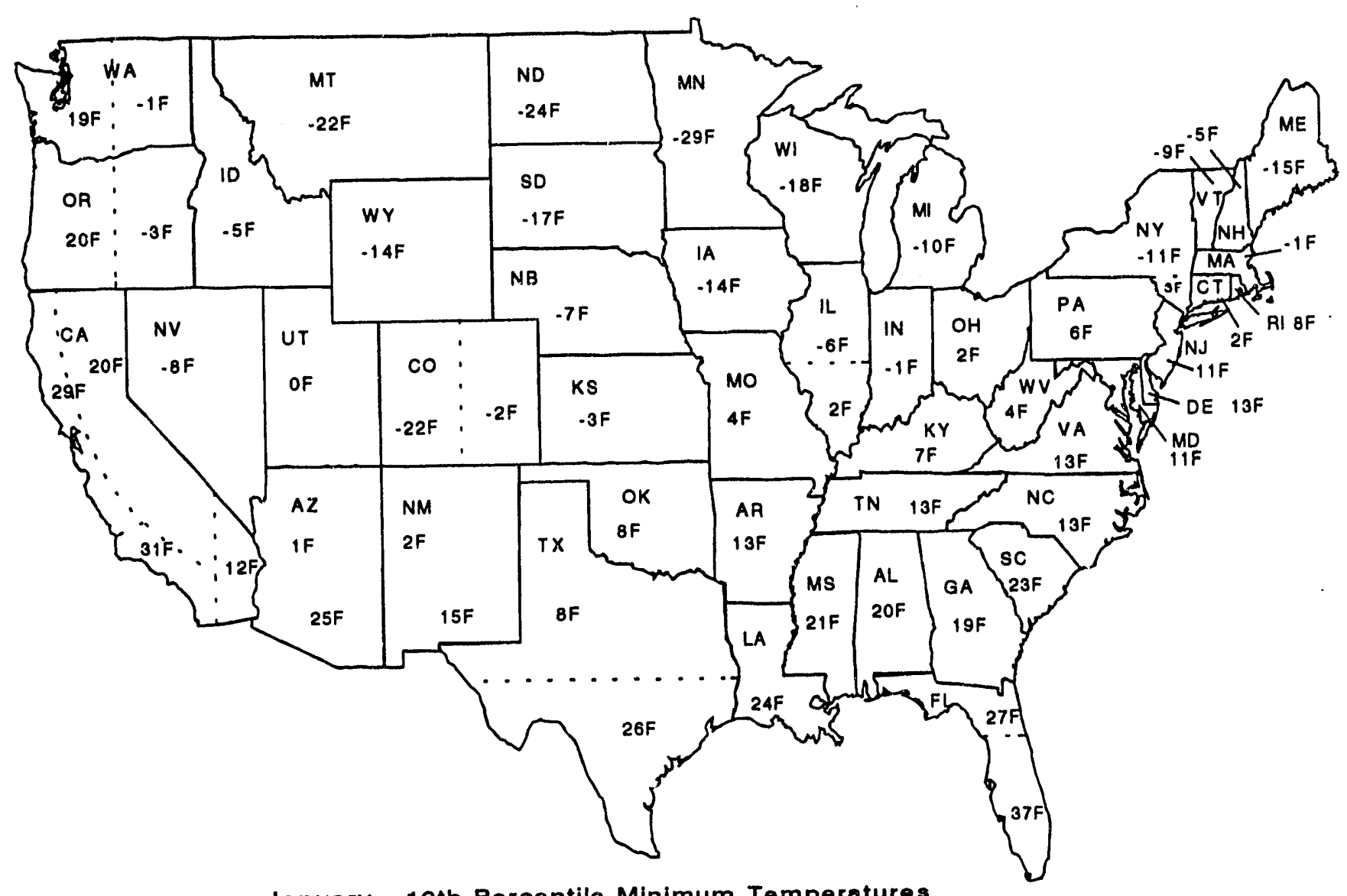

January - 10th Percentile Minimum Temperatures

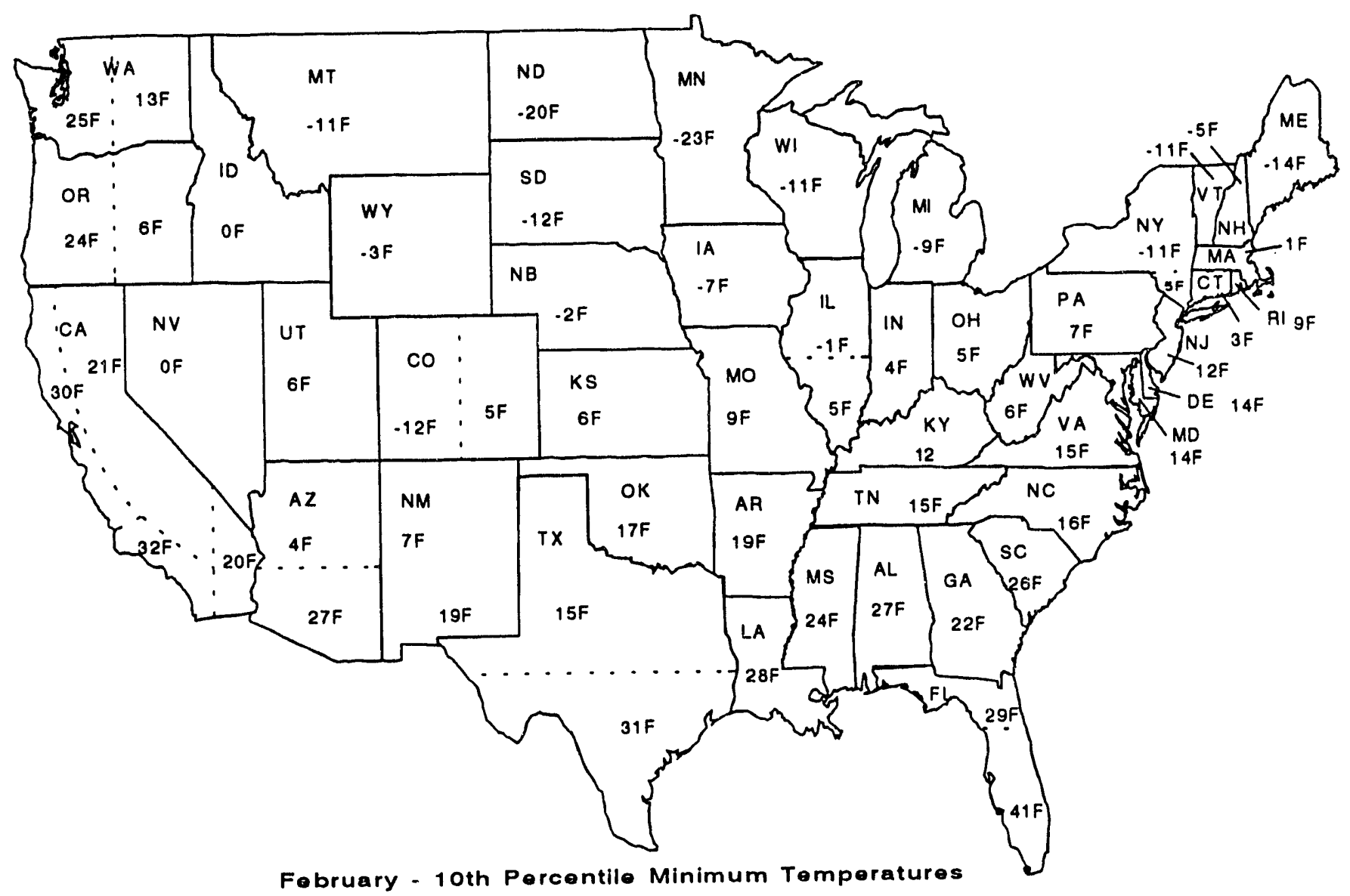

Figure 1. Tenth Percentile Minimum Temperatures for January and February 


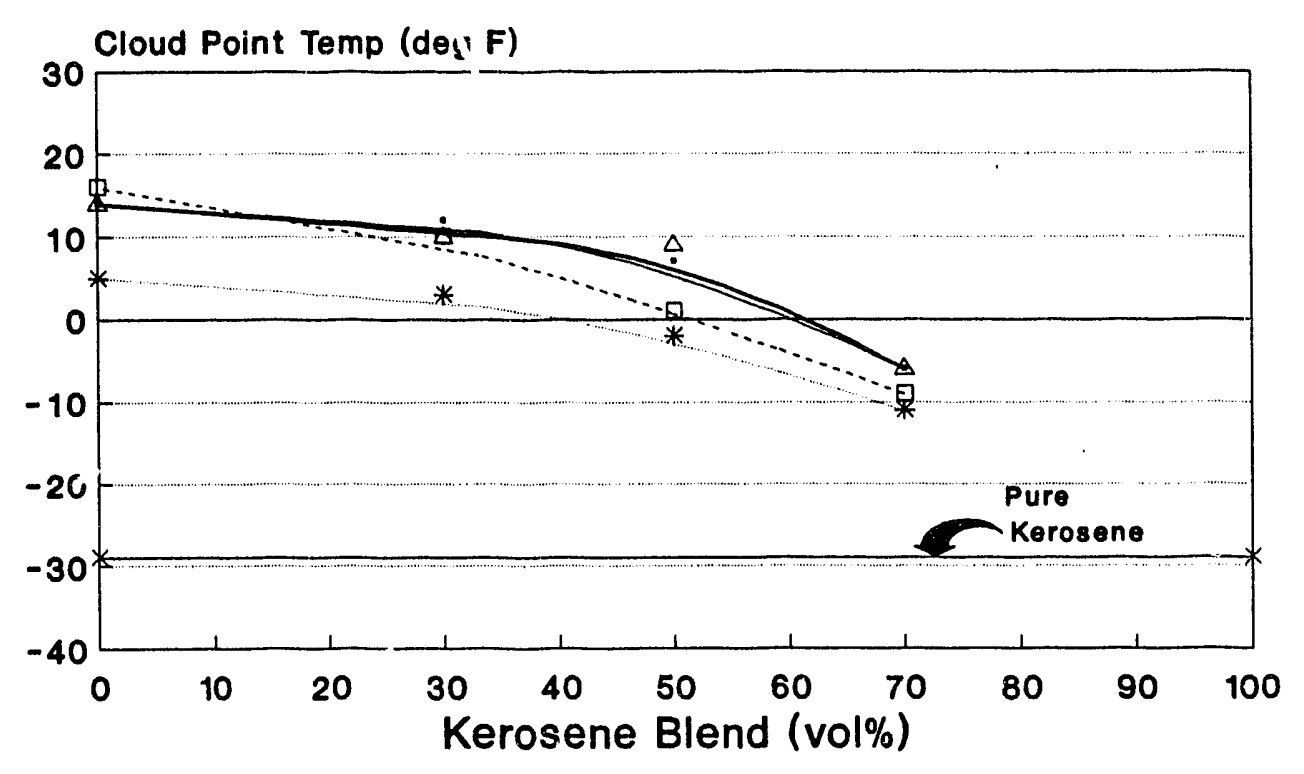

$\rightarrow$ Fuel $1 \multimap$ Fuel $2 *$ Fuel $3 \quad$ - 1 -Fuel 4

Figure 2 - Effect of Kerosene Blending on Cloud Point for Four Fuel Samples

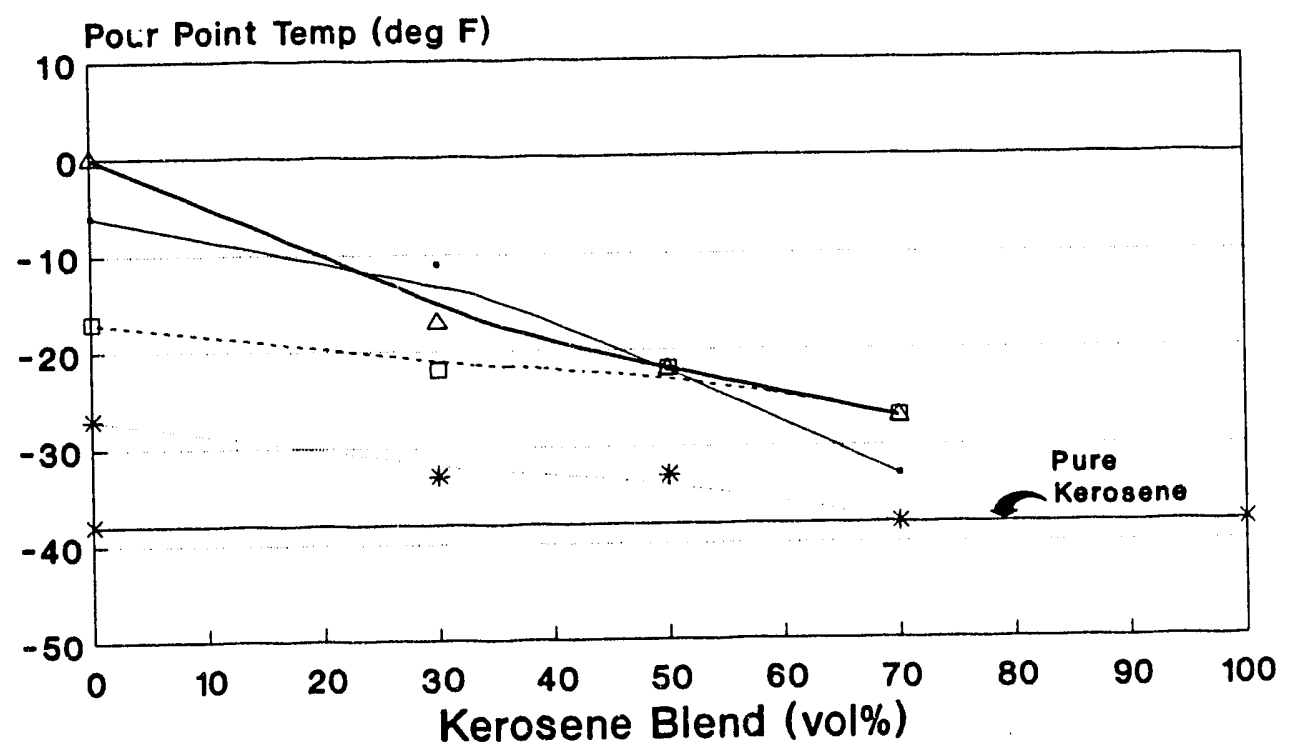

$\rightarrow$ Fuel $1 \multimap$ Fuel 2 * Fuel $3 \quad$-.-. Fuel 4

Figure 3 - Effect of Kerosene Blending on Pour Point for Four Fuel Samples 


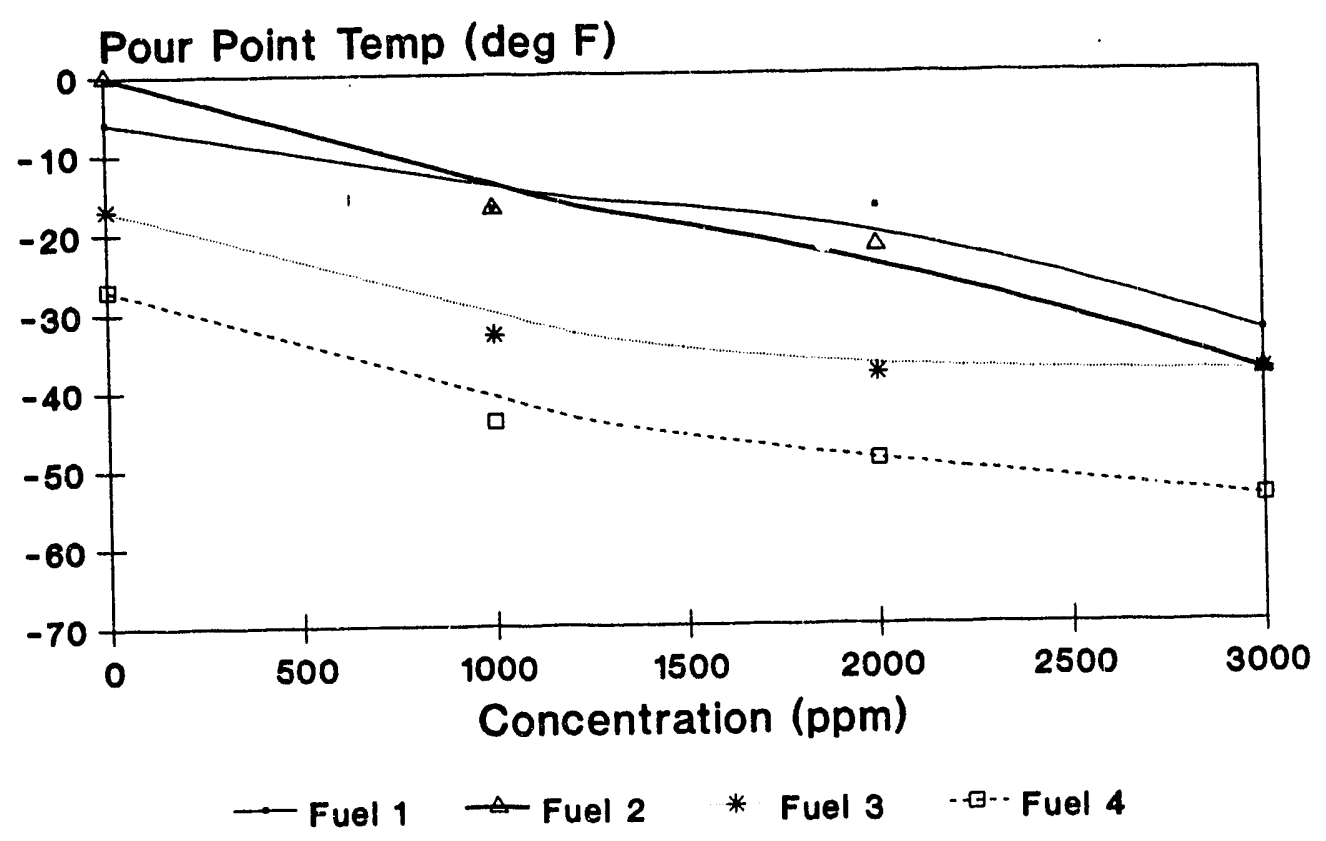

Figure 4 - Effect of Additive 1A on Pour Point of Four Heating Oil Samples

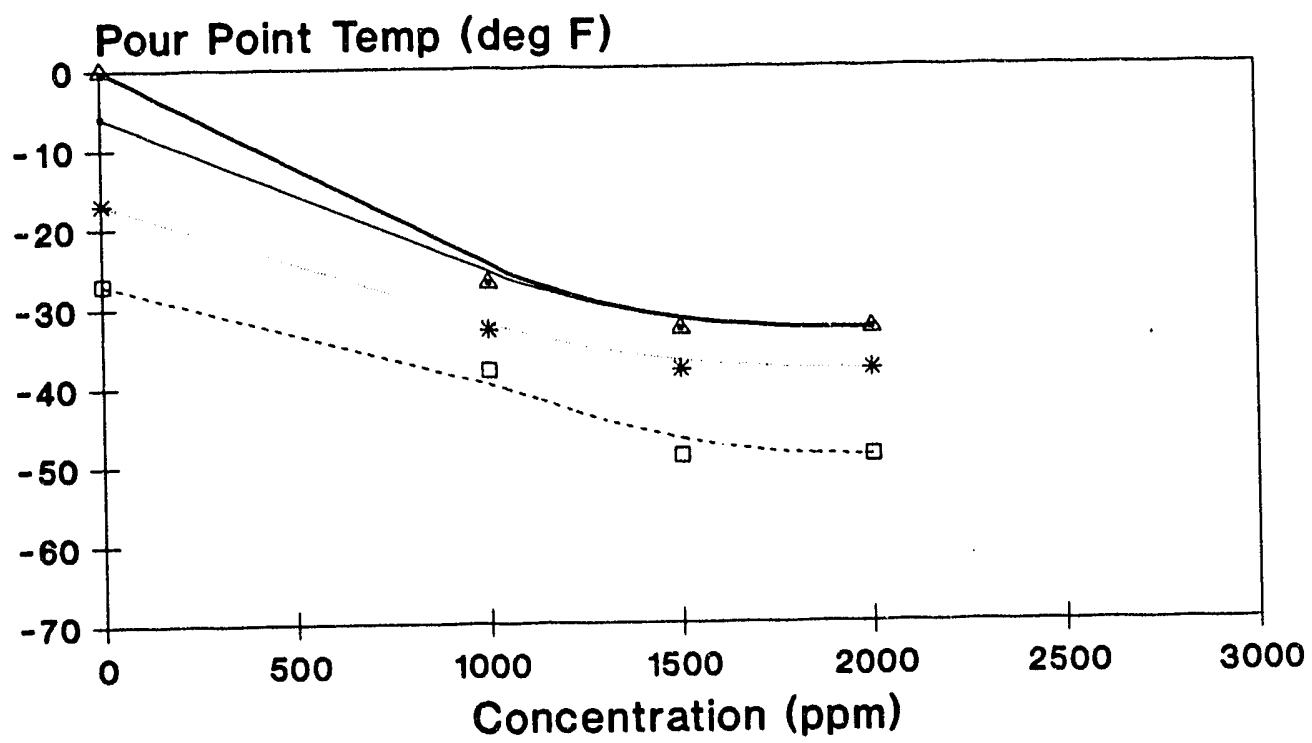

- Fuel $1 \rightarrow$ Fuel 2 * Fuel 3 - 9 -. Fuel 4

Figure 5 - Effect of Additive 1B on Pour Point of Four Heating Oil Samples 
The viscosity of the fuel also is sensitive to temperature. A viscosity-temperature profile is (Figure 6) shows that as temperature drops, the viscosity significantly increases. When this occurs, the total flow rate and atomization patterns of oil burner nozzles will be affected. With high viscous fuels, this can result in incomplete burning and higher emissions especially during each startup period as the burner turns on and off in response to $h$ :ating-load needs.

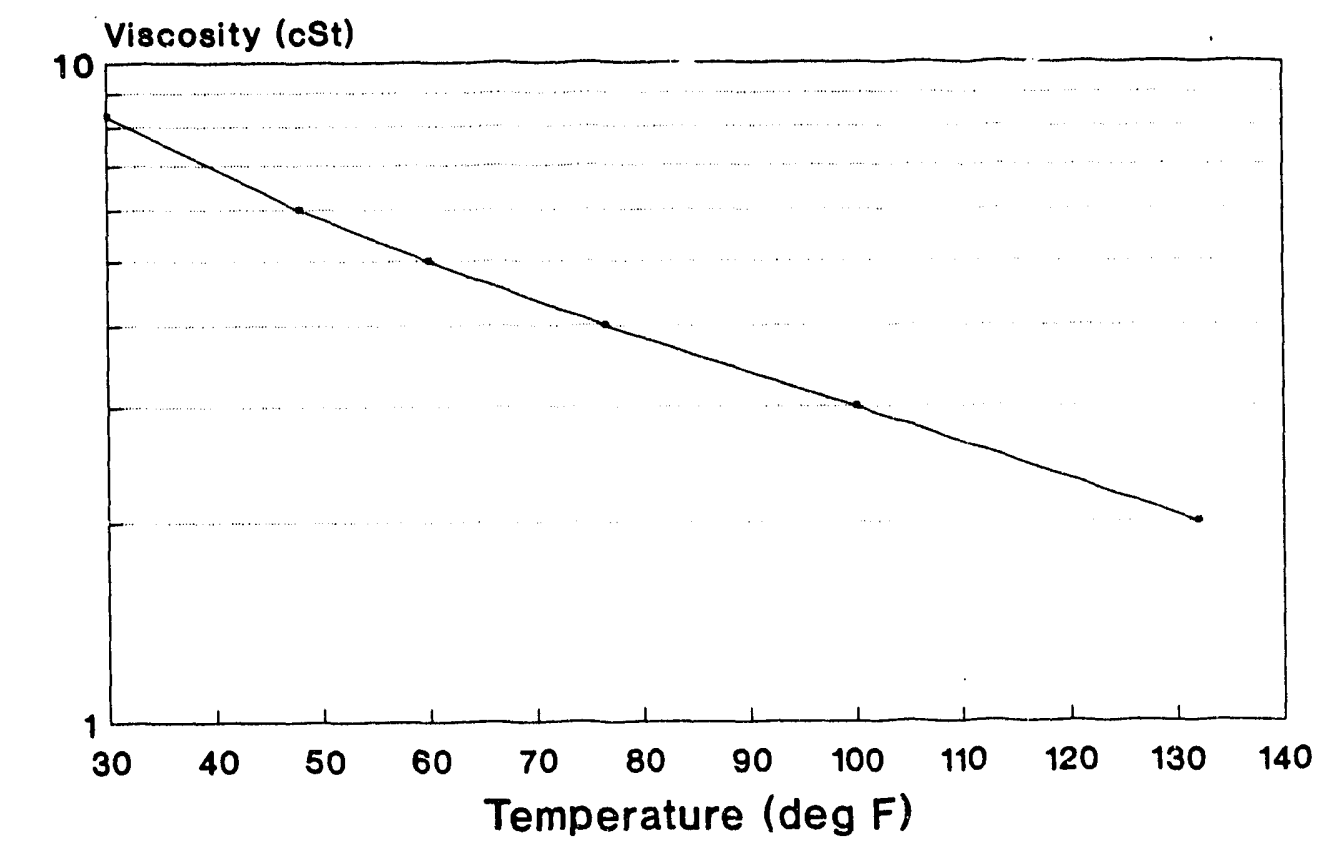

(Source: North American Combustion Handbook, 1986, North Amerlcan Mig. Co.)

Figure 6. Viscosity-Temperature profile for typical No. 2 fuel oil

During combustion, nozzle temperatures typically reach over $110^{\circ} \mathrm{F}$ and improved performance can be achieved if the oil is preheated to the nozzle's temperature. In the first minute after fuel ignition, during the transient period after burner startup, preheating the oil can be effective because this is when poor burning is most likely to occur.

Another method that can alleviate the flow problems associated with low temperatures is to use a one-pipe fuel supply system. A one-pipe system to the burner, applicable for aboveground tanks stored outdoors, provides fuel to the nozzle at a constant temperature. If the boiler is indoors, such as in a heated basement, the fuel will warm up to the ambient temperature. Some warm oil is always recirculated internally 
and retained within the pump housing. In a two-pipe system with a supply and return line, large volumes of cold fuel are recirculated to the burner from the outdoor tank.

Devices such as oil de-aerators used in one-pipe systems provide a convenient mechanism to minimize air within the supply line, while also maintaining a relatively constant temperature in the fuel line. Figure 7 shows a schematic of the device which is basically a small reservoir connected to the burner pump and to the tank by one suction line. Unburnt oil is recirculated to the device where the air escapes from the oil via a check valve and then is returned to the pump together with the oil from the tank.

The oil heat industry has expressed an interest in using oil de-aerators to preheat fuel to improve cold temperature operations. As part of this project, we determined the extent of preheating achievable to effectively improve operations. A time-temperature profile of a steady-state burner operation is shown in Figure 8. The burner was turned on at time, $\mathrm{t}=0$.

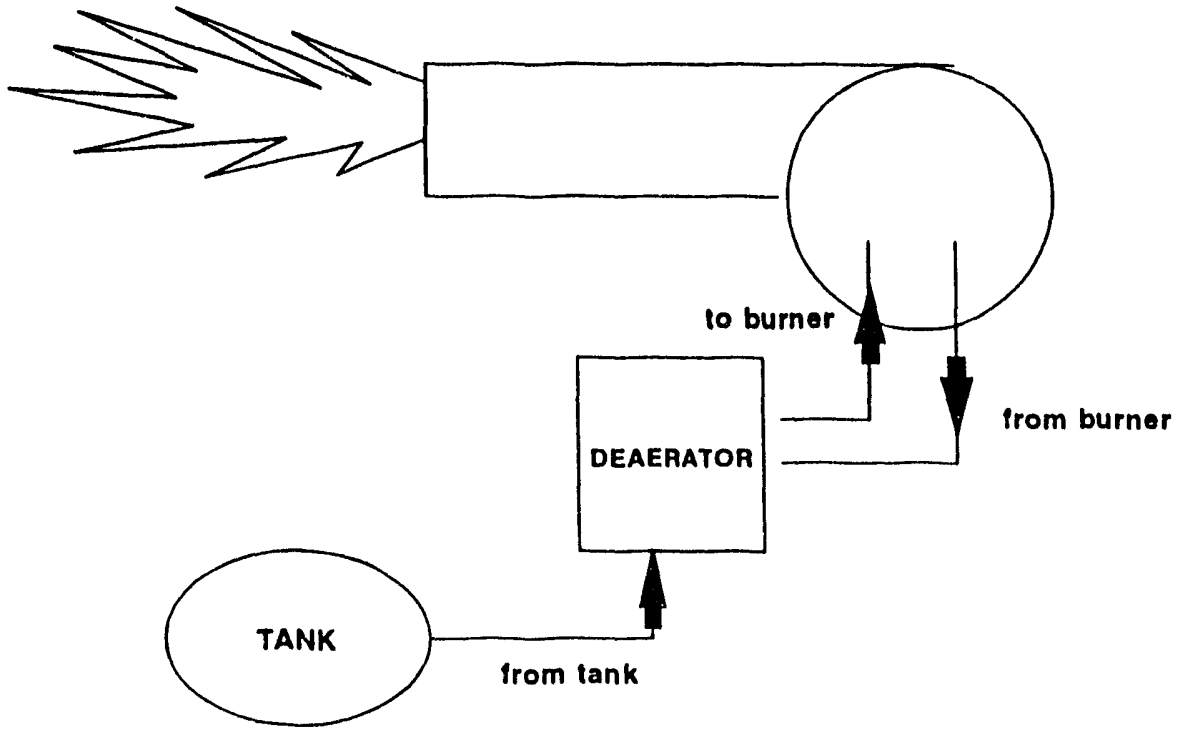

Figure 7 - Schematic of Oil De-aerator

Results show that the temperature of the oil coming from the tank only reaches a steady value of $24^{\circ} \mathrm{C}\left(75^{\circ} \mathrm{F}\right)$ (lines from and to burner), while the nozzle temperature reaches about $43^{\circ} \mathrm{C}\left(110^{\circ} \mathrm{F}\right)$. It takes 6 minutes for fuel temperatures to reach a steady maximum value and is not fast enough to change the characteristics of startup combustion (which occurs within 1 minute of ignition). Similar responses were observed during cyclic conditions. While this device is effective as a de-aerator, it provides no more benefits than a one-pipe system in terms of fuel preheating. Devices such as a nozzle line heater which preheats the fuel before it enters the nozzle can reduce smoke and improve atomization in cold weather [13]. 


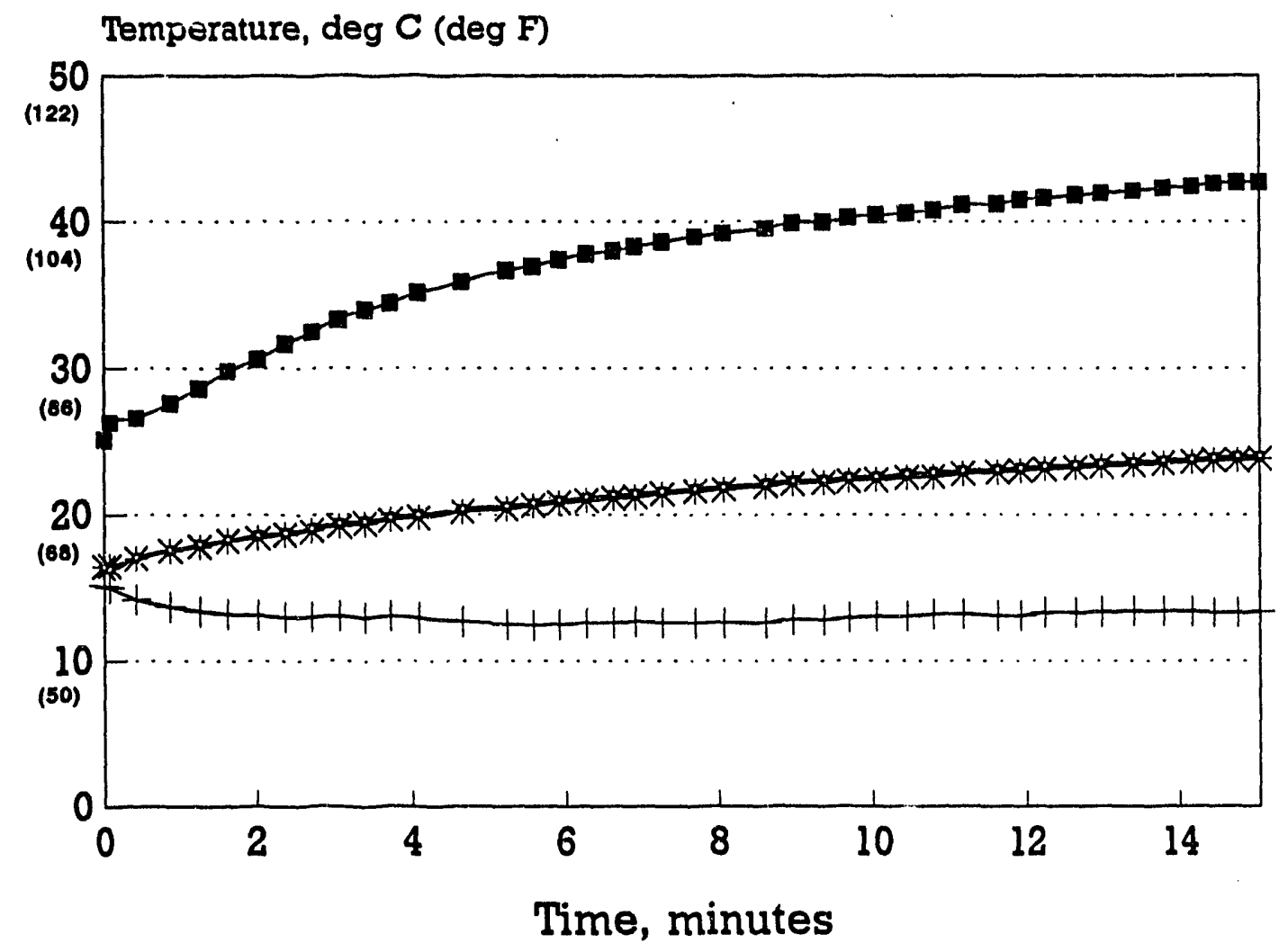

$\rightarrow$ line from burner + line from tank $*$ line to burner $\rightarrow$ nozzle

Figure 8 - Temperature-Time Profile of Oil in Deaerator

\subsection{Conclusions}

Low temperatures alter the physical properties of fuel, such as pour- and cloudpoints, and viscosity in such a way that it can significantly affect atomization, fuel transfer, and burner operations. To achieve satisfactory operations and minimize such problems as plugging of fuel lines and filters, and poor combustion during cold weather operations it is recommended that fuels be checked for cloud- or pour-point temperatures for appropriate use at specific region(s). Guidelines such as ASTM D-975 which provide recommended temperatures for all regions of the United States should be followed. The guidelines are applicable for both diesel and heating fuel.

When fuels are stored or encounter temperatures below the cloud- or pour-points, solvents or chemical additives may be used to achieve satisfactory operations. In order to select the best alternative between these two blending components, the temperature requirements and the costs per gallon of treated fuel to achieve the end result must be 
known. Fuel pre-heating devices can be used to lower the viscosity of cold fuel and improve fuel transfer through pipes and filters. 


\section{CONTAMINATION}

\subsection{Water and Microbial Contamination}

Fuel contamination is a common and major cause of the degradation of fuel quality which can result in a buildup of "sludge." The contaminants include water, microbiological growth, dirt and rust debris. When excessive materials settle to the bottom of the storage tank they form mats of sludge and can affect the operations of the heating and fuel-transfer equipment.

Contamination due to water and microorganisms is inevitable. Water can enter storage tanks through vents, fill pipes, and cracks, and condense on tank walls due to changes in air temperature. Microorganisms exist in the surrounding air, water, and soil and many types can thrive in the fuel which is used as a food source. Figure 9 illustrates the extent of the problem at each point as the fuel moves from the refinery to the home storage tank. Routine fuel monitoring for cleanliness and minimizing the amount of water entering the tank is a key factor in a preventative maintenance program that will reduce the associated common problems, such as plugged nozzles, fuel filters, and fuel lines.
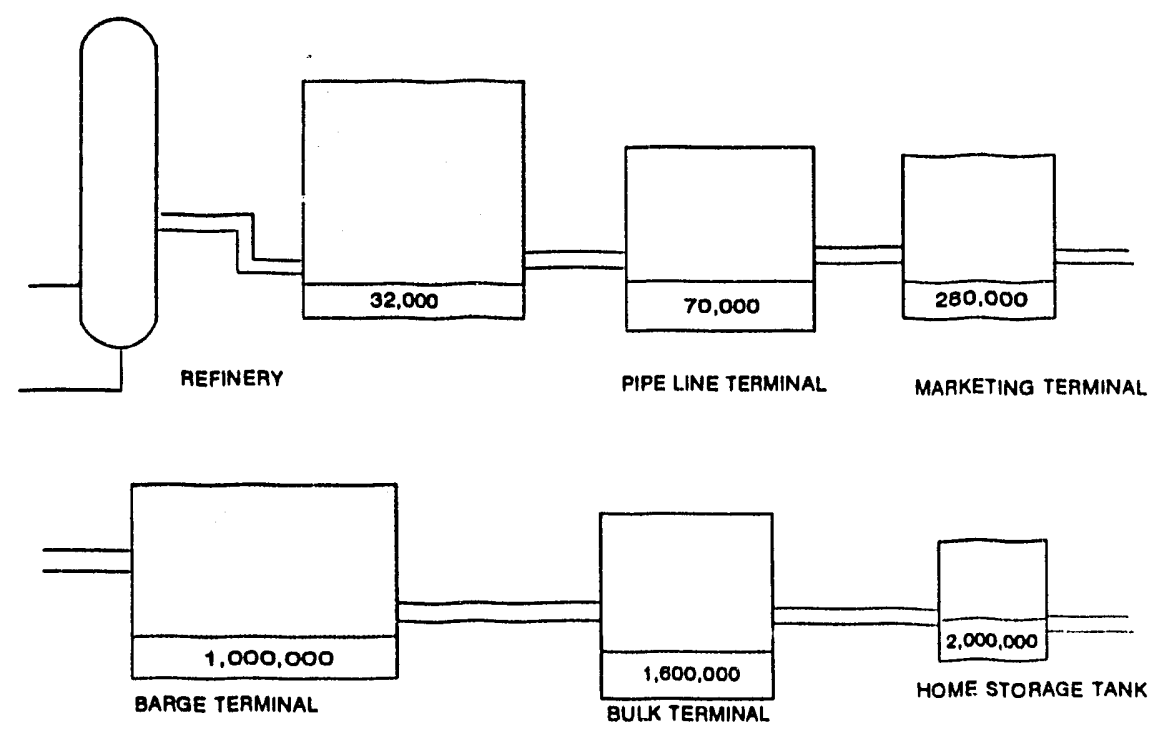

Figure 9 - Water Bottom Microorganism Populations in Heating Oil Distribution System (Colonies per Milliliter Water). Source [14] 


\subsection{Effects of Biocide}

One of the most effective ways to kill active microorganisms and inhibit further growth is to use biocides. An evaluation was made of the effects of selected biocides on different strains of microbes commonly found in fuel oil using four commercial additives which are readily availaible. These selected products are registered with the federal Environmental Prctection Agency (EPA) and are classified as pesticides. As such, they must at least meet the criteria for effectiveness as claimed by the manufacturers based on the recommended dosages. A general description of what is in the biocides is contained in the Appendix.

There are essentially three categories of microbes that are found in fuel oil: aerobic vacteria, anaerobic bacteria, and yeast/mold (fungi). These nicrobes were introduced inio samples containing a mixture of fuel and bottom water at concentrations simulating those found in a contaminated storage tank. Three days later, the microbes in the samples were counted. The anaerobic bacteria did not survive in any of the samples.

The biocides were added to individually fuel samples at three different concentration levels (low, manufacturer's recommended, and high doses); the control sample contained no additives. The details of the experimental procedures and the complete results are included in the Appendix. At specific intervals after the additive dosing, 48 hours and 1 week, the samples were analyzed. Microbe concentrations, expressed in colony forming units per milliliter $(\mathrm{cfu} / \mathrm{ml})$, were measured for each species as a function of time.

In general, biocides differ in their effectiveness for killing different species of microbes. A preliminary determination of the type of microbe infestation is essential in selecting the most suitable product. For active growth in the water portion of the stored fuel, a biocide must be partially soluble in the water phase to be effective in reducing microbial populations. 


\section{CLOSING DISCUSSIONS}

Requirements to meet federal regulations on fuel quality for mobile sources will impact heavily on the future quality of all distillate products. The trend towards heavier and more sour crude sources (with higher sulfur content) will mean that more products will need to be processed at the refineries and with greater severity to meet the increased demands for low sulfur diesel fuel. How these changes will affect the pool of heating oil has concerned the residential heating industry, and these issues have been discussed in this paper.

The studies that have been conducted in recent years by the EPA and the petroleum industry indicate that with major modifications to refinery configurations, capabilities will exist in the future to improve almost all distillate products in terms of lower sulfur content. The investment costs to just desulfurize on-road diesel will be very significant. However, refiners will be motivated to produce other low-sulfur products, such as heating oil, because of added costs involved to segregate these fungible products. Expecting that environmental regulations can only become tighter, refiners may be inclined to expand on their desulfurization capabilities now instead of adding them on later.

Benefits can accrue when using low-sulfur fuel in heating equipment, such as reduced sulfur-dioxide emissions, extended equipment wear, and reduced maintenance requirements. From a preliminary analysis that considers the environmental costs of pollutant emissions, the benefits or value of reduced sulfur oxide emissions appear to be comparable to the added costs of fuel desulfurization. The future availability of the higher quality product will depend greatly on the demands of the fuel marketer or enduser.

Many of the changes that degrade fuel quality result from poor storage conditions. Water and microbiological contamination cause problems associated with sludge buildup, tank corrosion, and the poor performance of heating equipment. Low storage or operating temperatures affect the fluidity of the fuel and make it more difficult to move through pipes and filters. These factors can be controlled by routine monitoring of the tank and fuel supply, keeping the tank dry and clean, and using chemical additives where appropriate. Preventative maintenance is the key to minimizing the problems of fuel quality. 


\section{REFERENCES}

[1] Coughlan, R.T. et. al. "An Overview of Residential Heating Fuel Quality, Interim Report", Brookhaven National Laboratory, BNL-45996 (Dec 1990).

[2 ] Energy Information Administration (EIA), Petroleum Supply Annual, 1981-1990, Department of Energy, DOE/EIA-0340(90)/1.

[3 ] "Regulatory Impact Analysis, Control of Sulfur and Aromatics Contents of OnHighway Diesel Fuel," U.S. Environmental Protection Agency, Office of Air and Radiation, Office of Mobile Sources (Jun 1990).

[4 ] "Diesel Fuel Quality Effects on Emissions, Durability, and Performance," Craig Miller and Christopher Weaver, Energy and Resource Consultants, Inc., and William Johnson and Terry Higgings, Sobotka and Co., Inc., EPA Contract 680106543 Report (Sept 1985).

[5 ] "Cost and Feasibility of Lowering Diesel Fuel Sulfur and Aromatic Content," Sobotka \& Co., Inc., Draft Final Report, EPA Contract 68-01-7288 (Nov 1987).

[6] "A Study on Restriction of Sulfur and Aromatics Content of Highway Diesel Fuel - An estimate of Economic Impact on the U.S., Refining Industry," Franklin PI Frederick, Bonner and Moore Management Science, Final Report EPA Contract 68-03-3353 (Jun 1988).

[7 ] "The U.S. Refining Industry: Facing the Challenges of the 1990s", Cambridge Energy Research Associates, Prepared for U.S. Department of Energy (Jan 1992).

[8 ] "U.S. Refining Industry Capability to Manufacture Ultra Low Sulfur Diesel Fuels," National Petroleum Refiners Association, Washington D.C. (1986).

[9] National Institute for Petroleum and Energy Research, Bartlesville, Oklahoma

[10] Compilation of Air Pollutant Emission Factors, AP-42, Stationary Point and the Area Sources, U.S. Environmental Protection Agency (1985).

[11] Butcher T., et. al.,"Sludge, Fuel Degradation and Reducing Fouling on Heat Exchangers," Brookhaven National Laboratory, BNL-47270 (Feb 1992).

[12] Schrepfer, M. W., Stansky, C. A., and Arnold, R. J.,"Middle Distillate Stability, Time for Reassessment,", UOP Inc., Presented at the National Petroleum Refiners Association, Fuels and Lubricants Meeting, Houston, TX, Nov 3-4, 1983. 


\section{REFERENCES}

[13] Butcher, T., et. al., "Impact of Burner Design Features on Sooting in Residential Oil Fired Systems, Brookhaven National Laboratory, BNL 52102 (Nov 1986).

[14] Hostetler, H.F. and Powers, E.J., "Bugs, Surfactants and Woes," Presented at the 28th Midyear Meeting of the American Petroleum Institute (May 1963).

[15] Ottinger, R., Wooley, D. R., Robinson, N. A., Hodas, D. R., Babb, S. E., Environmental Costs of Electricity, Oceana Publications, Inc. (1990).

[16] Batey, J.E., "Environmental Impact: Oil vs. Gas," Fuel Oil and Oil Heat Journal (Jun 1992). 


\section{APPENDIX}

EXPERIMENTAL DETAILS OF BIOCIDE TESTS 


\section{EXPERIMENTAL DETAILS FOR BIOCIDE TESTS}

Thirteen fuel samples, $220 \mathrm{ml}$ each, were evaluated, each containing $200 \mathrm{ml}$ of fuel and $20 \mathrm{ml}$ of "bottom water." Under controlled laboratory conditions, all samples were inoculated with a mixed microbial population: aerobic bacteria (Pseudomonas aeroginosa), anaerobic bacteria (Desulfovibrio desulfuricans), mold (Cladosporium resinae), and a strain of yeast that was already present in the fuel. The inoculation was designed so that the initial bacterial count would be around $5 \times 10^{7} \mathrm{cfu} / \mathrm{ml}$ (colony forming units per milliliter), the yeast around $5 \times 10^{4}$, and the mold around $1 \times 10^{4}$. These microbes usually thrive in the water layer when water is present in a fuel tank.

Three days after inoculation, samples were quantitatively evaluated for microbial survival. The samples were shaken vigorously and allowed to settle. After settling, the water portion was analyzed for total aerobic bacteria, anaerobic bacteria, yeast and mold (fungi). This measured microbial activity was considered the first analysis, at time $t=0$. Some variations in microbial activity from the initial inoculation concentrations were observed. Two days after these counts were done, the samples were dosed with biocides according to the concentration levels shown in the table on the next page (low dose, high dose, and recommended dose). At 48 hours and one week after dosing, surviving microbial populations were reassessed. Between the time of the first analysis $(a t=0)$ and the time the samples were dosed, the concentrations of surviving microbes would be expected to increase, as was observed in those cases where the measured concentrations at 48 hours were higher than at $t=0$. This indicates that the biocide is not necessarily ineffective, but rather, in that short duration before the first measurement at $t=0$ the microbial population had increased such that the benefits of the biocide appeared reduced.

\section{RESULTS}

Figures 10,11 , and 12 illustrate the effects of biocides on microbial populations at different treatment concentration rates. After one week, additive BB at the recommended and high doses controlled the yeast and mold but unable to significantly decrease the bacteria. Additive $\mathrm{PR}$, on the other hand, controlled all three microbial types at the high dose but only the mold at the recommended dose. After one week, at the high dose, SV was extremely effective in reducing all microbes with virtually no survival. However, additive KT at all three concentrations gave this effect at one week, and was even very effective after 48 hours. It is likely that additive KT was so effective in killing active microbial growth in part because of its complete solubility in water. Because the analysis of microbial activity has been limited to the water portion of the sample, an additive has to be soluble in the water phase at least to some extent. 


\section{BIOCIDE}

\begin{tabular}{||l|l|l|l|l||}
\hline & \multicolumn{1}{|c|}{ BB } & \multicolumn{1}{c|}{ PR } & \multicolumn{1}{c|}{ SV } & \multicolumn{1}{c|}{ KT } \\
\hline Active Ingredients & $\begin{array}{l}\text { Boron } \\
\text { compounds }\end{array}$ & Onyxide ${ }^{R}$ & $\begin{array}{l}\text { Morpholine } \\
\text { compounds }\end{array}$ & $\begin{array}{l}\text { Isothiazolone } \\
\text { compounds }\end{array}$ \\
\hline $\begin{array}{l}\text { Solubility } \\
\text { in Fuel }\end{array}$ & Complete & Complete & Complete & Slight \\
\hline $\begin{array}{l}\text { Solubility } \\
\text { in Water }\end{array}$ & None & Moderate & Moderate & Complete \\
\hline $\begin{array}{l}\text { Recominended } \\
\text { Treatment Rate }\end{array}$ & $270 \mathrm{ppm}$ & $500 \mathrm{ppm}$ & 500 & 100 \\
\hline Low dose & 135 & 200 & 250 & 50 \\
\hline High dose & 540 & 800 & 1000 & 200 \\
\hline
\end{tabular}

* Based on Manufacturers' information 

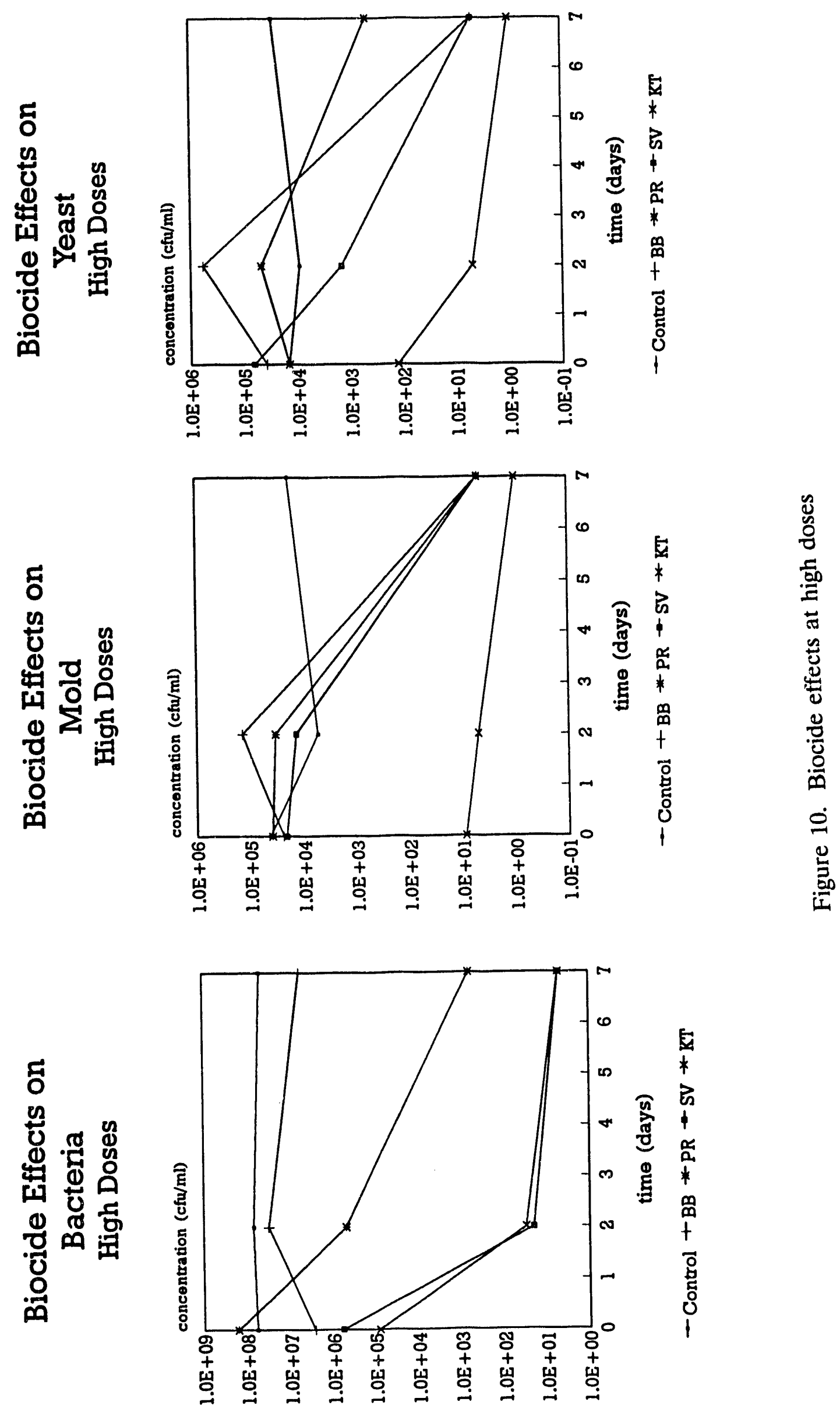

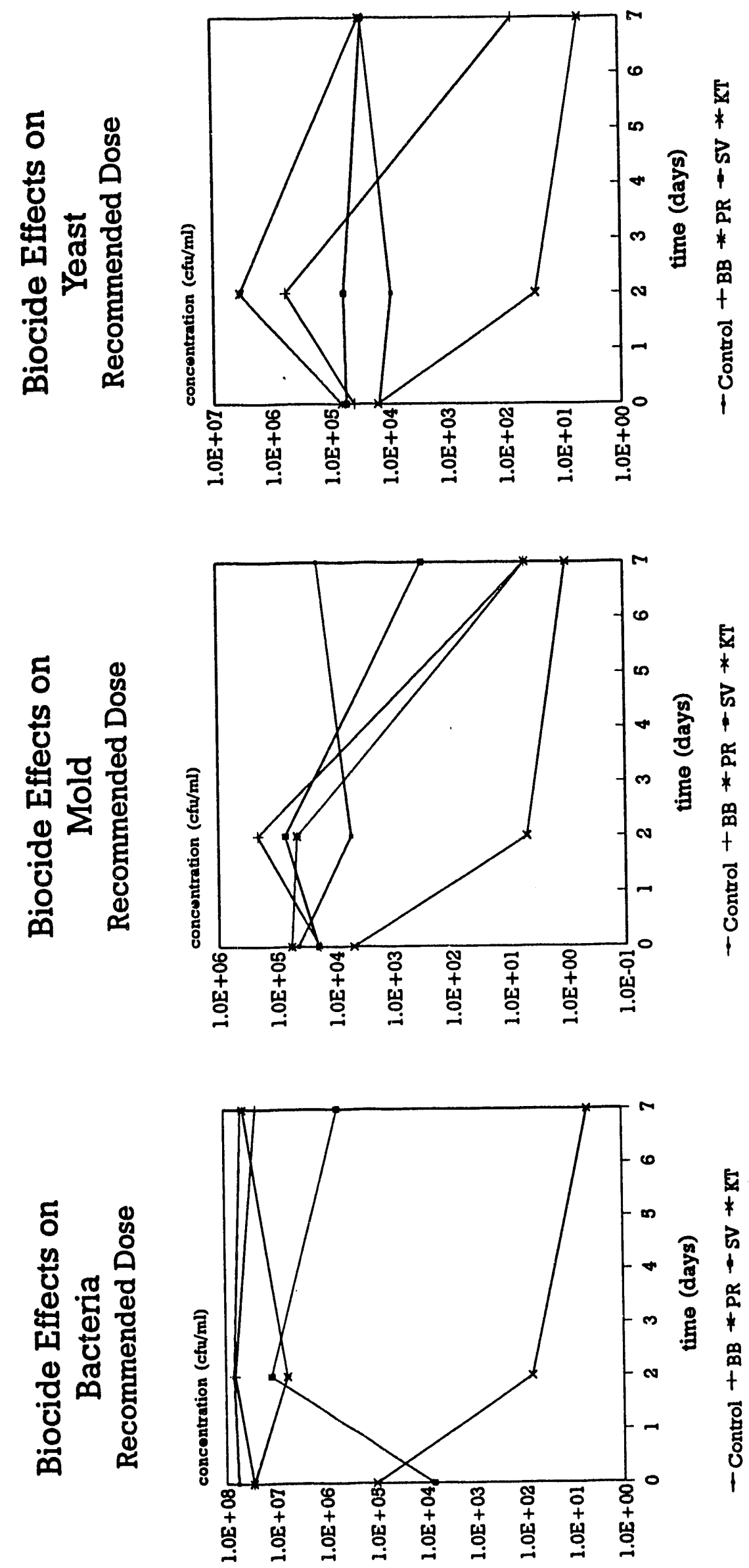

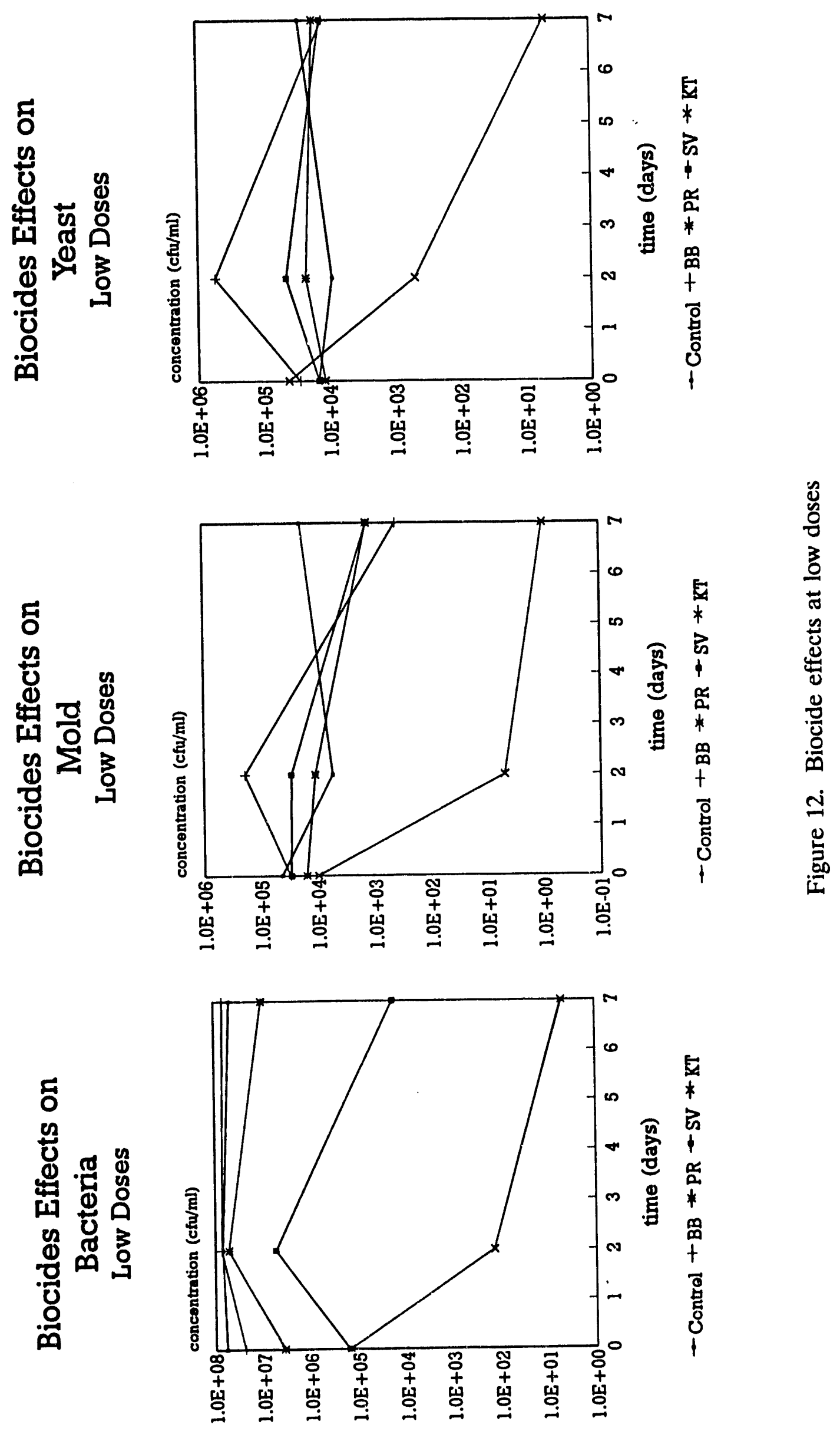

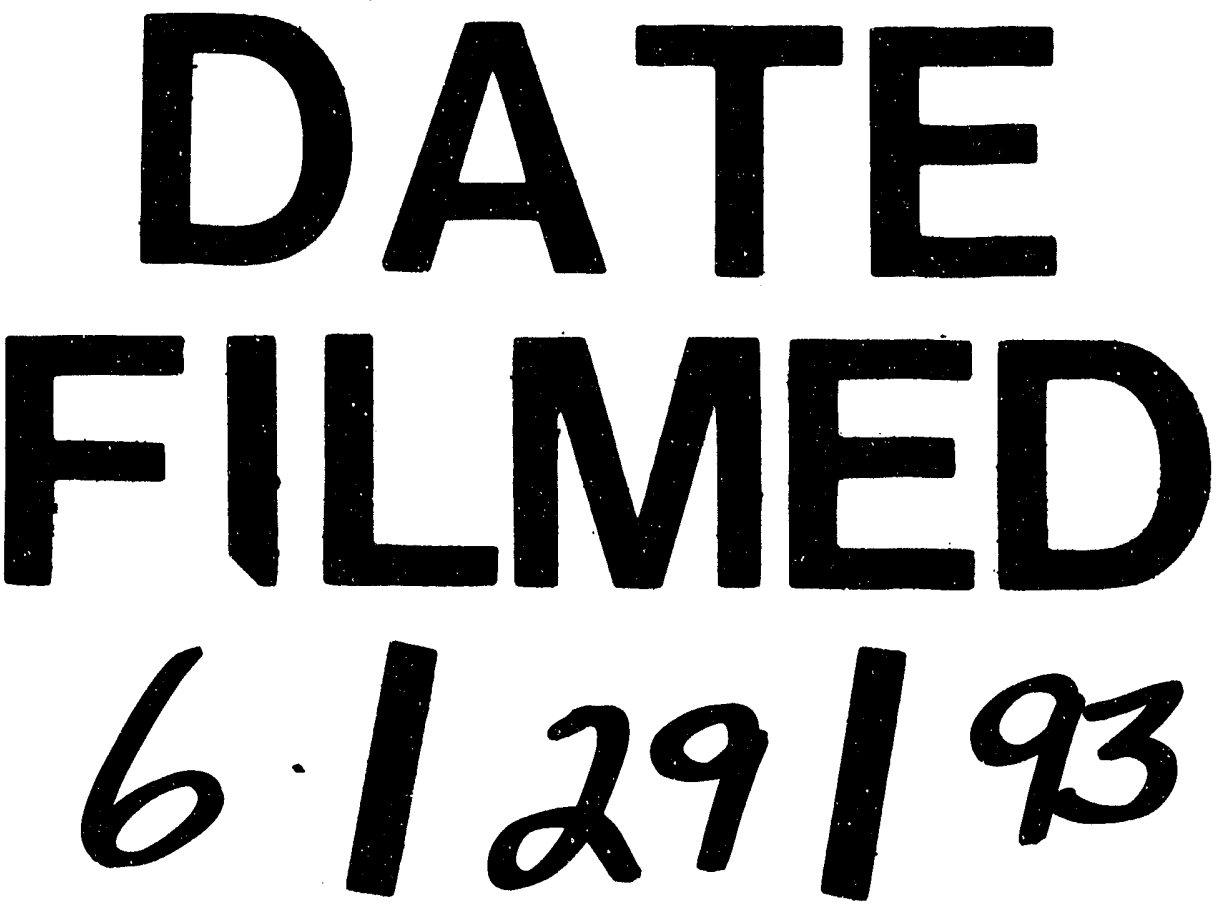
